\title{
The Yield, Intake and Animal Production of Four Tropical Grass Species Grown at Ibadan
}

\author{
F. O. Olubajo and V. A. Oyenuga \\ Department of Animal Science, \\ University of Ibadan, \\ Ibadan.
}

\section{SUMMARY}

The yield, intake and animal production of four grass species namely: Cynodon nlemfuensis var. robustus; Pennisetum purpureum Schum; Cynodon nlemfuensis var nlemfuensis (Ib8) and Panicum maximum Jacq., designated as treatments $\mathbf{M}, \mathbf{N}, \mathbf{P}$, and $Q$ respectively, were studied over a period of 1,226 days. Each treatment was grazed at three stages of growth - at four, six and eight week intervals.

Total dry matter yields for the experimental period ranged from approximately 22 tons for treatment $N$ grazed at intervals of four weeks to 65 tons for treatment $Q$ grazed at eight week intervals. The mean daily dry matter yield varied between approximately $18 \mathrm{~kg}$ for treatment $\mathrm{N}$ to $53 \mathrm{~kg}$ for treatment $\mathrm{Q}$ grazed at four and eight week intervals respectively.

With the exception of treatment $\mathbf{N}$, dry matter intake by sheep per $\mathrm{kg}$ of metabolic size per day decreased with increased maturity and ranged from $43 \mathrm{~kg}$ in treatment $\mathrm{N}$ to $86 \mathrm{~kg}$ in treatment $P$ grazed every four weeks.

Treatment means of liveweight increases of grazing White Fulani (Zebu) steers were $392 \mathrm{~g}$, $360 \mathrm{~g}, 337 \mathrm{~g}$ and $226 \mathrm{~g}$ per head per day for treatments $Q, N, P$ and $M$ respectively.

Though the protein content of the pastures was high enough even in the dry season to maintain the grazing animals, dry matter production and intake were usually very low.

\section{INTRODUCTION}

ATTEMPTS at finding out the productivity and the nutritive value of indigenous pasture mixtures under the intensive management system have received considerable attention at the University of Ibadan Research Farm since 1960. Okorie, Hill and McIlroy (1965) reported on the productivity and the nutritive value of mixtures of (a) Cynodon nlemfuensis var. robustus and Centrosema pubescens; (b) treatment (a) plus Chloris gayana and
Digitaria decumbens and (c) treatment (b) in association with Stylosanthes gracilis, using 2-year old N'Dama steers and White Fulani heifers asthe grazing animals over a two-year period. Oyenuga and Olubajo (1966); Olubajo and Oyenuga (1970 and 1971) gave detailed reports of the productivity, digestibility, voluntary intake and the animal production of three grass/ legume mixtures:- (d) Cynodon nlemfuensis var robustus plus Centrosema pubescens (e) treatment (d) in association with Stylosanthes gracilis; and (f) Digitaria decumbens, Centrosema pubescens and Stylosanthes gracilis, using White Fulani steers as the grazing animals over a period of four years. However, there has been no report given on the productivity and the nutritive value of pure stands of local grass species under the intensive grazing management.

The main objective of this paper is to summarise the results obtained when four local grass species grazed at three growth levels were measured over a period of 1,226 days under intensive grazing management pratices.

\section{MATERIALS AND METHODS}

A 3.64 hectare plot formerly used for grazing between 1962 and 1968 was cleared of its cover and divided into four equal plots of 0.91 ha each. Each plot was further divided into four equal strips of 0.228 ha and each strip was subdivided into 
six equal sub-plots of approximately 0.038 ha each. The plots were randomized and planted to the following grass species between July and September 1968.

Treatment

\begin{tabular}{|c|c|c|}
\hline & $\begin{array}{l}\text { Cynodon } \\
\text { robustus }\end{array}$ & nlemfuensis va \\
\hline $\mathrm{N}-\mathrm{g} \cos$ & $\begin{array}{l}\text { Pennisetum } \\
\text { Schum }\end{array}$ & purpureum \\
\hline & $\begin{array}{l}\text { Cynodon } \\
\text { nlemfuensis }\end{array}$ & nlemfuensis \\
\hline & Panicum & maxin \\
\hline
\end{tabular}

The sub-plots in each treatment were randomized such that grasses could be grazed or harvested at three different leves of maturity namely: four, six and eight weeks intervals.

\section{Application of Fertilizers}

No fertilizer was applied to the pastures in 1969 because it was not available in the country. In $1970,251 \mathrm{~kg} / \mathrm{ha}$ of tripple superphosphate was applied in two equal parts on May 13 and August 18 respectively. In $1971,251 \mathrm{~kg} / \mathrm{ha}$ of urea was applied on May 28 and August 17, respectively. In $1972,251 \mathrm{~kg} / \mathrm{ha}$ of sulphate of ammonia and approximately $126 \mathrm{~kg} / \mathrm{ha}$ of single superphosphate were applied in two instalments as in the two preceeding years.

\section{Grazing}

Due to lack of adequate rainfall and poor growth of the pastures grazing did not commence until September 1969. On September 29, 1969 twelve White Fulani steers ranging on the average from approximately $181 \mathrm{~kg}$ to $234 \mathrm{~kg}$ were randomly assigned to the treatments according to the regime to be grazed.
Pre-and post-grazing samples were taken from each sub-plot just before the animals were introduced and taken off each sub-plot. The samples were chopped to small pieces, thoroughly mixed and representative samples were taken for dry matter determination and proximate analysis which were carried out as described by Olubajo and Oyenuga (1970).

Animals were weighed before entering and on the day they were to be moved off the subplots.

A total of twelve indoor digestibility trials were conducted between August 1969 and December 1970 with twelve West African Dwarf rams with an average of three trials for each level of maturity. The details of the trials and procedure adopted are as described by Olubajo, Van Soest and Oyenuga, 1974.

\section{RESULTS}

Annual dry matter yield for the four grass species are presented in Table 1 .

\section{TABLE 1}

Estimated yield of Dry matter (m.t./ha/annum)

Age at Harvest

\begin{tabular}{crrr}
\hline Treatment & 4 Weeks & 6 Weeks & 8 Weeks \\
\hline M. & 51.0 & 53.3 & 49.1 \\
N. & 43.1 & 48.9 & 55.5 \\
P. & 56.3 & 57.4 & 60.6 \\
Q. & 50.8 & 59.8 & 63.6 \\
\hline
\end{tabular}

These figures are estimates from plot dry matter yield figures from September 26,1969 to February 26, 1973, a period of 1,226 days. The data in Table 1 indicate that there were progressive increases in dry matter yields in each of the pasture 
treatments with increasing maturity. The lowest estimated dry matter production of approximately 43 tons/ha/annum was recorded for treatment $\mathrm{N}$ harvested at intervals of four weeks and the highest figure of approximately 64 tons/ha/annum in treatment $Q$ harvested every eight weeks.
The data in Table 2 summarise the daily dry matter yields and the proportion of them that was utilized by the animals under grazing conditions. The data indicate that the percentage utilization of grass on offer in the field varied between approximately $50 \%$ in treatment Q

TABLE 2

Yield of dry matter $(\mathrm{kg})$ per day and $\%$ dry matter utilized

\begin{tabular}{lcccccc} 
Treatment & $\begin{array}{c}4 \text { Weeks } \\
\text { kg. }\end{array}$ & $\begin{array}{c}\% \\
\text { Utilized }\end{array}$ & $\begin{array}{c}6 \text { Weeks } \\
\mathrm{kg}\end{array}$ & $\begin{array}{c}\% \\
\text { Utilized }\end{array}$ & $\begin{array}{c}8 \text { Weeks } \\
\mathrm{kg}\end{array}$ & $\begin{array}{c}\% \\
\text { Utilized }\end{array}$ \\
\hline H. & 21.26 & 60.96 & 33.34 & 55.89 & 40.93 & 54.31 \\
N. & 17.96 & 61.98 & 30.56 & 59.44 & 25.31 & 54.64 \\
P. & 23.48 & 54.98 & 35.88 & 52.03 & 50.50 & 53.61 \\
Q. & 21.17 & 54.84 & 37.37 & 54.40 & 53.02 & 50.39 \\
\hline
\end{tabular}

when harvested at intervals of eight weeks to approximately $62 \%$ in treatment $\mathrm{N}$ when grazed every four weeks. The mean percentage utilization for each species was approximately $57.0,59.0,54.0$ and
53.0 for treatments $\mathrm{M}, \mathrm{N}, \mathrm{P}$ and $\mathrm{Q}$ respectively.

The chemical composition data shown in Table 3 indicate that the crude protein content varied between approximately

TABLE 3

Mean chemical composition of pre-grazed grass species expressed as percentage of dry matter during May 1969 to December 1971

\begin{tabular}{lcccccccc}
\multicolumn{1}{c}{ Species } & Age & D.M. $(\%)$ & SiO-free \\
& (weeks) & at harvest & 2 & Ash & C.P. & C.F. & E.E. & N.F.E. \\
Cynodon & 4 & 27.42 & 5.89 & 15.87 & 33.56 & 1.21 & 43.47 \\
nlemfuensis & 6 & 27.90 & 5.78 & 13.52 & 33.00 & 1.14 & 46.50 \\
var. robustus & 8 & 31.22 & 5.24 & 11.01 & 34.65 & 1.11 & 47.99 \\
Pennisetum & 4 & 16.49 & 9.21 & 17.08 & 30.29 & 1.62 & 41.80 \\
purpureum & 6 & 17.35 & 8.76 & 13.86 & 31.96 & 1.58 & 43.84 \\
& 8 & 18.75 & 7.59 & 12.50 & 33.34 & 1.57 & 45.00 \\
Cynodon & 4 & 28.46 & 5.97 & 14.29 & 34.70 & 1.52 & 43.52 \\
nlemfuensis & 6 & 30.15 & 7.31 & 12.90 & 34.75 & 1.40 & 43.64 \\
var. nlemfuensis & 8 & 32.54 & 5.25 & 11.52 & 35.45 & 1.32 & 46.46 \\
Panicum & 4 & 21.44 & 6.05 & 13.90 & 34.77 & 1.24 & 44.04 \\
maximum & 6 & 23.49 & 6.47 & 12.25 & 35.24 & 1.20 & 44.84 \\
& 8 & 25.37 & 6.20 & 11.12 & 36.25 & 1.13 & 45.30
\end{tabular}

$17.0 \%$ in treatment Nharvested atfourweeks and $11.0 \%$ in treatment $M$ grazed every eighth week. There were little or no variations between treatments when grazed at the same stages of growth.
The crude fibre content varied little within each species though there were slight increases with advanced maturity. The content ranged from $30.3 \%$ in treatment $\mathrm{N}$ harvested at intervals of 
4 weeks to approximately $36.3 \%$ in treatment $Q$ harvested at intervals of eight weeks.
The dry matter intakes expressed per kilogramme metabolic size of sheep in digestion trials are shown in Table 4.

TABLE 4

Dry Matter Intake by Sheep $(\mathrm{g} / \mathrm{kgW} 0.75$

\begin{tabular}{ccccc} 
Treatment & \multicolumn{4}{c}{ Age at harvest } \\
1969 & 4 weeks & 6 weeks & 8 weeks & \\
M & 47.1 & 50.0 & 55.6 & \\
N & 53.8 & 55.6 & 62.1 & \\
P & 42.4 & 60.3 & 57.5 & \\
Q & 49.5 & 63.5 & 59.9 & \\
1970 & & & & \\
M & 58.9 & 71.1 & 48.4 & \\
N & 36.8 & 43.6 & 46.8 & \\
P & 42.4 & 50.3 & 55.3 & \\
Q & 40.1 & 62.3 & 51.2 & \\
& & & & \\
M & 53.0 & 60.6 & 52.0 & Overal Mean \\
N & 45.3 & 49.6 & 54.4 & $49.8 \pm 4.70$ \\
P & 42.4 & 55.3 & 56.4 & $51.4 \pm 7.62$ \\
Q & 47.7 & 62.9 & 55.6 & $55.4 \pm 7.60$ \\
S.E. & & $3.44 \mathrm{~g}$ & &
\end{tabular}

The data in the table indicate that on the average, treatment $Q$ gave the highest mean dry matter intake per kilogramme of metabolic size $\left(55.4 \pm 7.60 \mathrm{~g} / \mathrm{KgW}{ }^{0.75}\right.$ and treatment $\mathrm{N}$ the lowest intake of $49.8 \pm 4.27 \mathrm{~g}$. The mean intake ranged from approximately $42.4 \mathrm{~g} / \mathrm{kgW}{ }^{0.75}$ in treatment $\mathbf{P}$ for pastures harvested at four weeks of regrowth to approximately $62.9 \mathrm{~g} / \mathrm{kgW} 0.75$ in treatment $\mathrm{Q}$, cut at intervals of six weeks. The range of dry matter intake over the feeding trial periods was from approximately $36.8 \mathrm{~g} / \mathrm{kgW}^{0.75}$ in treatment $\mathrm{N}$ cut at four weeks to 63.5 $\mathrm{g} / \mathrm{kgW}^{0.75}$ in treatment $\mathrm{Q}$ cut at intervals of six weeks.

The apparent dry matter digestibility results, the actual intake $(\mathrm{kg} /$ day), the digestible dry matter intake (D.D. M.I.) and the mean live weights $(\mathrm{kg})$ of the West African dwarf sheep used as experimental animals are presented in Table 5. The data on digestibility indicate that the two tall growing grass species had the lower apparent dry matter digestibility at any stage of growth than either of the two Cynodon grass species. The overall mean dry matter digestibility of $53.4 \%$ obtained in treatment $\mathrm{Q}$ was significantly $(\mathrm{P}<0.05)$ lower than the figure of $64.2 \%$ for treatment $M$ and more significantly so $(\mathrm{P}<0.01)$ than the digestibility figure of $66.4 \%$ obtained in treatment $\mathrm{P}$, even though there were no significant differences in the intakes of dry matter and digestible dry matter between the treatments by the experimental animals. 
TABLE 5

Sheep-Digestion Trials (August 1969-December 1970)

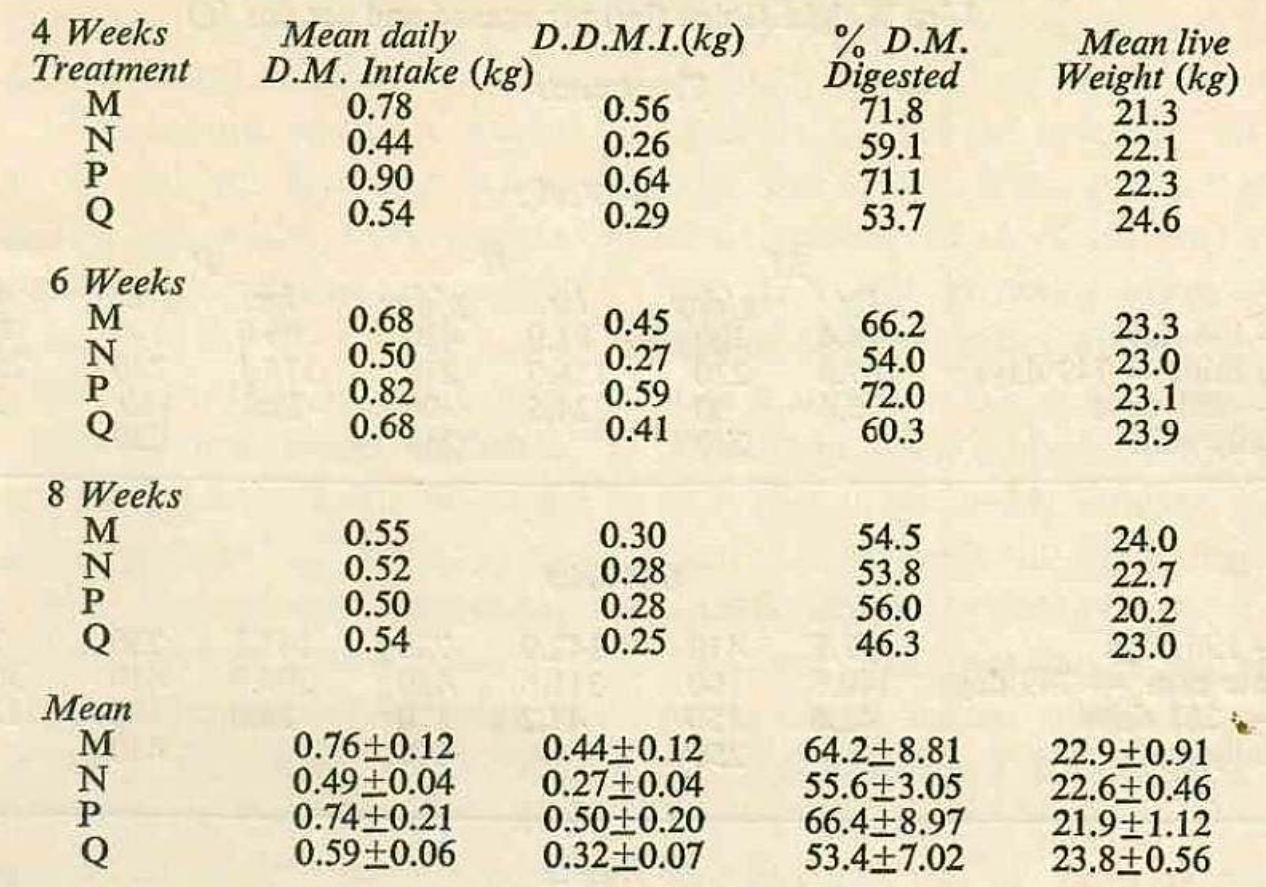

In Table 6 are presented data of mean total live weight increases (or loss) of the grazing cattle per head per day and per season during the experimental period.

\section{DISCUSSION}

The estimated figures of dry matter yields of 43.2 tons, 48.9 tons and 55.5 - tons per ha per annum for Pennisetum purpureum (treatment $\mathrm{N}$ ) when grazed at intervals of 4,6 and 8 weeks respectively are possible in practice if water is available all year round. Little, Vicente and Abruna (1959) reported yields of dry matter of approximately 58 tons/ha/annum for heavily fertilized ( $897 \mathrm{~kg} \mathrm{~N} / \mathrm{ha} /$ annum) irrigated. Pennisetum purpureum pasture and a yield of 46.8 ton/ha/annum for similarly treated $P$. maximum pasture. Oyenuga (1959 and 1960) reported lower dry matter yields of $18.1,20.9$ and 33.9 tons/ha/annum for elephant grass planted in unfertilized plots and harvested over a period of twelve months at 6,8 and 12 weeks intervals; and D. M. yields of $16.0,15.0$ and 23.0 tons/ha/annum for $P$. maximum harvested at the same stages of maturity. These figures are much lower than the yield of 47 tons/ha/annum reported by Little et al., (1959). Report from Adiopume, Ivory Coast (Crowder and Chheda, 1973) indicated that if well-managed Pennisetum purpureum could attain a dry matter yield of between 30 to 40 tons/ha/annum. The same authors reported a dry matter yield of 20tons/ha/annum for Cynodon nlemfuensis var. nlemfuensis (IB.8).

The percentage utilization of herbage in the field (Table 2) was highest for Pennisetum purpureum (treatment N) and lowest for Panicum maximum. This trend can be explained on the basis of the lower crude fibre content of Pennisetum purpureum (Table 3) at the stages of maturity it was grazed. Olubajo, Van Scest and 
TABLE 6

Live Weight Gains (kg) per season and per day (g)

Treatments

\begin{tabular}{|c|c|c|c|c|c|c|c|c|}
\hline \multirow[b]{2}{*}{$\begin{array}{l}\text { Early rain - } 196 \text { days } \\
\text { Mid- \& Late rains }-749 \text { days } \\
\text { Dry season }-281 \text { days } \\
\quad \text { Mean daily gain }\end{array}$} & & & & & \multicolumn{2}{|c|}{$P$} & \multicolumn{2}{|c|}{$Q$} \\
\hline & $\begin{array}{r}k g \\
74.4 \\
167.8 \\
25.4\end{array}$ & $\begin{array}{l}\text { g/day } \\
380 \\
220 \\
90 \\
230\end{array}$ & $\begin{array}{c}\mathrm{kg} \\
83.9 \\
156.5 \\
24.5\end{array}$ & $\begin{array}{l}\text { g/day } \\
430 \\
210 \\
90 \\
243\end{array}$ & $\begin{array}{c}\mathrm{kg} \\
99.8 \\
175.1 \\
-22.0\end{array}$ & $\begin{array}{l}\text { g/day } \\
510 \\
230 \\
-80 \\
220\end{array}$ & $\begin{array}{r}k g \\
84.8 \\
253.1 \\
20.9\end{array}$ & $\begin{array}{l}g / \text { day } \\
430 \\
340 \\
70 \\
280\end{array}$ \\
\hline
\end{tabular}

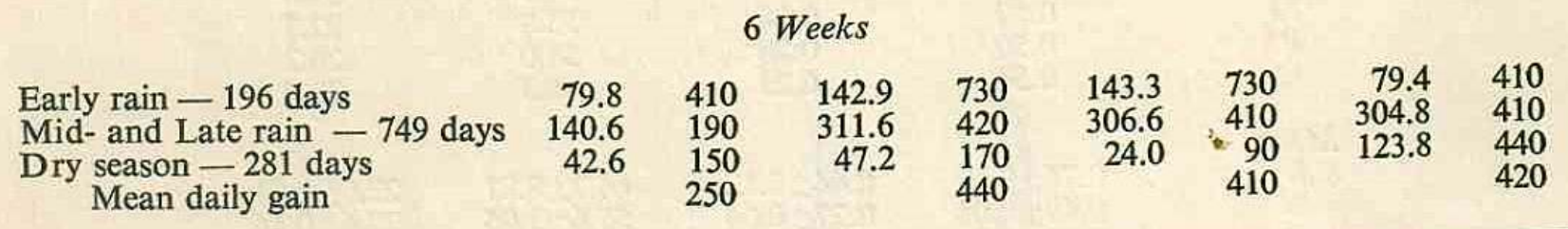

\begin{tabular}{|c|c|c|c|c|c|c|c|c|}
\hline \multicolumn{9}{|c|}{8 Weeks } \\
\hline $\begin{array}{l}\text { Early rains - } 196 \text { days } \\
\text { Mid- and Late rains - } 749 \text { days } \\
\text { Dry season }-281 \text { days } \\
\quad \text { Mean daily gain }\end{array}$ & $\begin{array}{r}38.1 \\
224.1 \\
26.8\end{array}$ & $\begin{array}{l}190 \\
300 \\
100 \\
197\end{array}$ & $\begin{array}{r}142.9 \\
196.4 \\
57.2\end{array}$ & $\begin{array}{l}730 \\
260 \\
200 \\
397\end{array}$ & $\begin{array}{r}144.7 \\
233.1 \\
25.4\end{array}$ & $\begin{array}{r}740 \\
310 \\
90 \\
380\end{array}$ & $\begin{array}{l}118.4+ \\
200.0^{*} \\
25.9^{*}\end{array}$ & $\begin{array}{l}890 \\
340 \\
200 \\
477\end{array}$ \\
\hline & & & leans & & & & & \\
\hline $\begin{array}{l}\text { Early rains } \\
\text { Mid- Late rains } \\
\text { Dry season }\end{array}$ & $\begin{array}{r}64.1 \\
177.5 \\
31.6\end{array}$ & $\begin{array}{l}327 \\
237 \\
113\end{array}$ & $\begin{array}{r}123.4 \\
221.5 \\
43.0\end{array}$ & $\begin{array}{l}630 \\
297 \\
153\end{array}$ & $\begin{array}{r}129.3 \\
238.3 \\
9.1\end{array}$ & $\begin{array}{r}660 \\
317 \\
33\end{array}$ & $\begin{array}{r}94.2 \\
252.6 \\
56.9\end{array}$ & $\begin{array}{l}577 \\
363 \\
237\end{array}$ \\
\hline
\end{tabular}

Oyenuga (1974), and Johnson, Guerrero and Pezo (1973) have reported that the lignin content of $P$. purpureum at 6 weeks of growth is about $4 \%$ while those of the other grass species used in this experiment varied between $5.3 \%$ and $6.4 \%$ at the same stage of growth. Besides, $P$. purpureum had the highest crude protein content of any of the grass species at any of the stages of maturity investigated. The mean percentages utilization obtained in this experiment even for grass species grazed at intervals of eight weeks are higher than the mean utilization figure of $41 \%$ each for mixtures consisting of Cynodon nlemfuensis var. robustus plus Centrosema pubescens, and of the above mixture in association with Stylosanthes gracilis reported by Olubajo (1969), and of the mean figure of approximately $44 \%$ reported by Okorie et al., (1965) for a mixture of Cynodon nlemfuensis var. robustus, Centrosema pubescens, Stylosanthes gracilis, Chloris gayana and Digi- 
taria decumbens. The explanation for the lower figures for the pasture mixtures lies in the fact that legumes in general, tend. to contain higher content of lignocellulose than grasses. This would tend to lower the efficiency of utilized herbage when taken in a mixture than when pure stands of grass species were grazed at comparable stages of growth.

The mean crude protein content and possibly the energy consumed indicate that they were sufficiently high enough to support good growth of animals as indicated by the live weight increases shown by the experimental animals during the course of study. The loss in live weights of animals grazing the four week old Cynodon 1B.8 (treatment P, Table 6) in the dry season was not due to low protein content of the pasture but rather to insufficient dry matter and therefore, energy intake during this period. The range of approximately 11.0 to $17.0 \%$ crude protein obtained in the present studies is in agreement with the results of previous workers (Oyenuga, 1957 and 1959 Minson, 1971; Chheda and Akinola, 1971).

The level of dry matter intake by the experimental sheep in digestion trials seemed to be adequate since no losses in weight were observed in these animals during the digestion periods. In general there were decreases in actual dry matter intakes with increasing maturity. Expressed per unit of metabolic size, dry matter intake was highest for grass species grazed at intervals of six weeks and this is also reflected in live weight increases (Table 6). The overall mean of $55.4 \mathrm{~g} / \mathrm{kgw}^{0.75}$ obtained in the present studies for Panicum maximum is about $17 \%$ lower than the mean intake of the same species by sheep fed under stall conditions in Australia (Minson, 1971) and is in agreement with the intake figures of $43.9 \mathrm{~g}, 55.8 \mathrm{~g}$ and $63.5 \mathrm{~g} / \mathrm{kgW}^{0.75}$ for low, medium and high levels of feeding Andropogon gayanus hay (Zemelink, Haggar and Davies, 1972).

The best performances on the basis of animal production were obtained from grasses grazed at intervals of six weeks and the lowest from grasses grazed every four weeks. It is of interest to note that the two tall growing grass species with much lower intakes and lower digestibilities resulted in better live weight increases than the Cynodon species. The explanation for this is probably due to the fact that the test animals in digestion trials were sheep which normally prefer to graze pastures with finer leaves better than those with broad leaves while cattle which are the animals used to measure live-weight increases probably preferred the tall growing species to the characteristically low growing ones such as the Cynodon species. Cynodon nlemfuensis var nlemfuensis gave the lowest gains during the dry season. The low performances shown by the two Cynodon grass species during the dry season is attributable to the high content of lignin present in these species. Olubajo et al., (1974) have shown that as early as four weeks of regrowth the lignin content of these species was as high as $6 \%$, while that of the tall growing species was about $4.5 \%$. The best performance was given by all species during the early rains with an over-all mean increase of $660 \mathrm{~g}$ per head per day in treatment $P$ and $327 \mathrm{~g}$ per head per day in treatment $M$.

Analysis of variance showed highly significant differences $(\mathrm{P}<0.005)$ in the daily live weight increases between seasons, between years of grazing and between treatment. The interaction between treatments and years of grazing were not statistically significant. The difference between treatments $\mathrm{P}$ and $\mathrm{Q}, \mathrm{Q}$, and $\mathrm{N}$, and treatments $\mathrm{N}$ and $\mathrm{P}$ were not statistically significants. Treatments $\mathrm{N}$ and $\mathrm{P}$ were significantly superior to treatment $M$ 
$(\mathrm{P}<0.05)$ while treatment $\mathrm{Q}$ was significantly superior to treatment $M(P<0.01)$ Daily live weight increases made by steers grazed on pastures at their 6th week of regrowths were significantly superior $(\mathrm{P}<0.01)$ to gains made on pastures grazed every four weeks, while the gains made by steers grazing pastures at intervals of eight weeks were significantly higher than those on four weeks regrowths $(P<0.05)$. The differences in gains by animals on pastures grazed at four and six weeks intervals were not significant.

\section{CONCLUSION}

The results obtained in these studies indicate that pure stands of grass species when well managed can produce about the same live weight increases as grass/ legume mixtures. However, there are usually very little materials for animals to graze during the dry season. This calls for dry season supplementation with etiher industrial food processing wastes such as citrus or pineapple peels and pulps or good quality hay or silage.

\section{REFERENCES}

ChHEda, H.R., and AkINola, J.O. (1971). Effects of cutting frequency and level of applied nitrogen on crude protein production and nitrogen recovery by three Cynodon strains. West Afr. J. Biol. and Appld. Chem. 14, 31-38.

Crowder, L.v', and ChHedA, H.R. (1973). Forage and Fodder crops in West Africa (A monograph).

Johnson, W.L., Guerrero, J., and Pezo, D. (1973). Cell-wall constituents and In Vitro digestibility of Napier Grass (Pennisetum Purpureum). J. Agric. Sci. Camb. 35, 1255-1261
LITTLE, S. Vicente, J., and ABRUNA, F. (1959). Yield and protein content of irrigated Napier Grass, Guinea Grass, and Pangola Grass as affected by nitrogen fertilization. Agron.J. 51, 111-113.

Minson, D.J. (1971). Digestibility and voluntary intake of six varieties of Panicum maximum. The Austr.J. Agric. and Anim. Husb. 11, 18-25.

OKoRIE, I., HILL, D.H., and McIlroy, R.J. (1965) The productivity and nutritive value of Tropical Grass/Legume pastures rotationally grazed by N'Dama cattle at Ibadan, Nigeria. J. Agric. Sci. Camb. 64, 235-245.

Olubajo, F.O. (1969). Assessment of the productivity, digestibility and the nutritive value of tropical pastures at Ibadan. Ph.D. Thesis, University of Ibadan, Ibadan, Nigeria.

Olubajo, F.O., and Oyenuga, V.A. (1970). Digestibility of tropical pasture mixtures using the indicator method. J. Agric. Sci. Camb. 75, 175-181.

Olubajo, F.O., and Oyenuga, V.A. (1971). The measurement of yield, voluntary intake and animal production of tropical pasture mixtures. J.Agric. Sci. Camb. 77, 1-4.

Olubajo, F.O., Van Soest, P.J., and Oyenuga, V. A. (1974). Comparison and digestibility of four tropical grasses grown in Nigeria. $J$. Anim. Sci. 38, 149-153.

OYenUGA, V.A. (1957). The composition and agricultural value of some grass species in Nigeria. Emp. J. Expt. Agric. 25, 237-255.

OYENUGA, V.A. (1959). Effect of frequency of cutting on the yield and composition of some fodder grasses in Nigeria. (Pennisetum Purpureum Schum). J. Agric. Sci. 53, 25-33.

OYENUGA, V.A. (1960). The effect of stage of growth and frequency of cutting on the yield and chemical composition of some Nigerian grasses. Panicum maximum Jacq. J. Agric. Sci. $55,339-350$.

Oyenuga, V.A. and Olubajo, F.O. (1966). Productivity and nutritive value of tropical pasture at Ibadan. Proc.X Inter. Grassld. Congr. Helsinki pp. 962-969.

Zemmelink, G., Hagger, R.J., and Davies, J.H. (1972). A note on the voluntary intake of Andropogon gayanus hay by cattle asaffected by level of feeding. Anim. Prod. 15, 85. 